\title{
Kronika domu jezuitów w Poznaniu i Dziennik Jana Wielewickiego SJ
}

\section{Dziennik...}

\section{A} utor Dziennika, Jan Wielewicki, urodzil się olsoło 1566 r. we wsi Wielowicz koło Sępólna Krajeńskiego, wstąpił do jezuitów 20 XII 1584 r. w Braniewie, zmarł 24 VII 1639 r. w Jarosławiu. Studia filozoficzne i teologiczne odbył na terenie Rzeczypospolitej w Poznaniu i Wilnie. Pełnił funkcję selkretarza prowincjała w latach 1599, 1607 i 1623. Był superiorem domów w Toruniu 1608-1609, Przemyślu 1611-1613, rektorem wspólnot we Lwowie 1613-1617 i Poznaniu 1625-1629, prepozytem ${ }^{1}$ domu profesów w Krakowie w latach 1619-1623, 1629-1633 i 1636. Napisał Historici diarii domus professae Societatis Iesu Cracoviensis, która została wydana w serii Scriptores Rerum Polonicarum, t. 7 (1579-1599), 10 (1600-1608), 14 (1609-1619) i 17 (1620-1629), w latach 1881-1899 zawierająca lata 1579-16392. Ostatni piąty tom ukazał się w $2004 \mathrm{r}$., chociaż był zapowiadany już w latach sześćdziesiątych przez Jana Poplatka SJ. Wielewicki współpracował $z$ Filipem Alegambe przy wydaniu Bibliotheca scriptorum Societatis Iesu, publikacji zawierającej życiorysy przedstawicieli zakonu jezuitów. Życie i twórczość autora Dziennika naclal czeka na pełne opracowanie. W swoim dziele Wielewicki umieścił dużo informacji o sobie samym, co może stanowić dla przyszłych badaczy podstawę do pełnej monografii.

Dziennik napisany jest w potocznej lacinie. Rozpoczyna się krótkim opisem sprowadzenia jezuitów do Polski przez kardynała Stanisława Hozjusza. Ułożony chronologicznie, chociaż czasami zdarzają się powroty do wcześniejszych wydarzeń lub wykorzystywanie faktów zawartych w pierwszych tomach podczas opisywania dziejów dla niego współczesnych. W miarę opisywanych zdarzeń są one coraz bardziej szczególowe, pierwszy tom obejmuje lat clwadzieścia, a ostatni tylko siedem.

Pierwsze notatki czynił od czasów rokoszu Zebrzydowskiego, co zaznaczył w swojej pracy ${ }^{3}$. Jak wynika $z$ jego życiorysu przebywał w wielu wspólnotach zakonnych na terenie Rzeczypospolitej, pod względem poszukiwania źródeł szczególne znaczenie ma jego kilkukrotny pobyt w Krakowie w domu profesów. Zamieszkiwali tu zakonnicy, którzy złożyli cztery śluby. Pierwszy taki dom powstał w Krakowie przy kościele św. Barbary w 1591 r. Utrzymywał się z jałmużny, profesi zajmowali się działalnością naukową i duszpasterską. W domu tym rezyclowal prowincjał zakonu, mieściły się tu także archiwa. Przybywali do niego najważniejsi goście Towarzystwa Jezusowego. Można domniemywać, że Wielewicki mial pełny dostęp do wszystkich źródel. Wykorzystal m.in. Dziennik osobisty Piotra Skargi, korzystał także $z$ diariuszy sporządzanych we wspólnocie jezuitów w Krakowie, a które nie zachowały się do czasów współczesnych. Prowadził bardzo szeroką korespondencję ze współbraćmi z całej 
Europy, którzy dostarczali mu opisów swoich państw i referowali najważniejsze wydarzenia. Opisy wojen, które miały miejsce za jego życia były tworzone na podstawie relacji kapelanów - bardzo często byli nimi jezuici. Bezpośrednio spotkał się z królem Zygmuntem III, gdy ten odwiedzał z małżonką wspólnotę jezuitów w Krakowie w 1606 r., poznał między innymi wojewodę poznańskiego Hieronima Gostomskiego, dane mu było wysłuchać relacji z wyprawy Dymitra Samozwańca $z$ ust legata papieskiego - Andrzeja Ławnickiego.

Praca pisarska Wielewickiego cieszyła się dużym uznaniem wśród przełożonych zakonnych, a szczególnie prowincjała Andrzeja Gutterea, który przeczytał cały Dziennik i zabronil dokonywania w nim jakichkolwiek zmian. Przyczynił się także Wielewicki do powstania podobnego Dziennika we wspól nocie jezuitów we Lwowie, którego autorem był Maciej Wielewicz i doprowadzil swoje dzieło do $1669 \mathrm{r}^{4}$. Kronika ta była kontynuowana aż do kasaty zakonu w XVIII w., Dziennik zaś Wielewickiego nie doczelkal się kontynuatorów.

\section{Kronika domu poznańskiego}

Kronika zachowała się w Archiwum Archidiecezji Warszawskiej pod sygn. 440 jako: Acta et Historia Collegii Posnaniensis Societatis Iesu 1574-1606 (dalej HPCSI), w formacie $18 \times 35$, strony ponumerowane ręcznie.

Napisana została w formie kodeksu obejmującego lata 1574-1606. Przyczyny powstania tego dzieła należy upatrywać w zarządzeniu kurii generalnej Towarzystwa w Rzymie, która wydlała w 1574 r. dekrety zobowiązujące do spisywania historii poszczególnych kolegiów, fundacji przelożonych wspólnot zakonnych. Jakub Wujek pełniący obowiązki rektora w Poznaniu zlecił prace nad spisywaniem kroniki o. Piotrowi Atriedzie - Hiszpanowi z pochodzenia. Ze względu na kłopoty w zakonie o. Atrieda nie mógł się z tej pracy wywiązać, rozpoczął jednak kronikę i pisał ją do 1576 r. Tym, co różni ją od Dziennika to bardzo dokładny i systematyczny zapis. Praktycznie każdy dzień wspólnoty jezuickiej ma swoje odzwierciedlenie w Kronice.

Jakub Wujek przez okres swojego pobytu w Poznaniu, co można prześledzić w korespondencji do generała zakon ${ }^{5}$, ubolewał nad ciągłym brakiem czasu na uzupełnienie kroniki. Zobowiązywał się jedynie do sporządzania sprawozdań rocznych, co realizował i przesyłał do kurii w Rzymie.

Kronika poznańska zawiera bardzo cenne informacje o pierwszych kongregacjach Towarzystwa w Polsce. Pełniła początkowo funkcję oficjalnego zapisu uczestników zebrań przełożonych zakonnych do $1578 \mathrm{r}$.

Pierwsza kongregacja Towarzystwa w Polsce odbyła się w Boszewie ${ }^{6}$ koło Pułtuska 18-27 stycznia $1576 \mathrm{r}$. Brał w niej udział m. in. Jakub Wujek jako jeden $z$ pierwszych Polaków profesów zakonu w Rzeczypospolitej. Obok niego zebrali się tam również: Franciszek Sunyer (prowincjał), Stanisław Rozdrażewski, Filip Widmanstadt (rektor z Braniewa), Jan Sesenionanus, Stanisław Warszewicki (rektor $z$ Wilna), Jerzy Fricius (rektor $z$ Jarosławia) i Stanisław Grodzicki (rektor $z$ Pultuska). Pierwszego dnia obrad ustalono delkretem, iz wszystkie decyzje podejmowane będą jednomyślnie. Sekretarzami kongregacji zostali wybrani Warszewicki i Grodzicki, jako przedstawicieli kongregacji wybrano Filipa Wid- 
manstadta i Jakuba Wujka?. Postanowiono, że Postylla katolicka Wujka nie będzie tłumaczona na język łaciński, aby mogła swoim zasięgiem trafić clo jak największej grupy odbiorców. Ustalono translację nazwy zakonu na język polski. Przyjęto i zobowiązano się upowszechniać nazwę Towarzystwo Jezusowe ${ }^{8}$.

Druga kongregacja jezuitów również oclbyła się w Boszewie. 22-28 września 1578 r. obradowali czołowi przedstawiciele Towarzystwa. Sekretarzem obrad został wybrany Jakub Wujek, pełniący wtedy jeszcze funkcję rektora w Poznaniu, ale już posiaclający nominację na przełożonego kolegium w Wilnie. Uczestnikami narad byli również: Alfon Pisanus, Stanisław Rozdrażewski, Filip Widmanstadt (rektor z Braniewa), Jan Sesonianus, Piotr Skarga, Adrian Bronus, (jako profesi zakonu) i Jan Konarski (wicerektor $z$ Poznania), Stanisław Grodzicki (rektor z Pułtuska) i Stanisław Herbertus (wicerektor z Jarosławia) ${ }^{9}$. Przy nazwisku Jakuba Wujka umieszczono zapis „wicerektor $z$ Wilna”. Warto zwrócić uwagę, że w literaturze przedmiotu powtarza się informacja, że już na kongregacji pełnił on funkcję rektora, czyli w otoczeniu najważniejszych osób zakonu. Wynika z tego, ze Wujek był zastępcą rektora w stolicy Wielkiego Księstwa Litewskiego we wrześniu 1578 r. i po spotkaniu przełożonych otrzymal godność rektorską. Faktycznie jednak, mimo wcześniejszego tytułu wicerektora, pełnił już obowiązki rektorskie ze wzglęlu na nieobecność Stanisława Warszewickiego ${ }^{10}$.

Od końca lat osiemdziesiątych kongregacje odbywały się zasadniczo w Wilnie, dlatego jak należy przypuszczać kronika poznańska straciła na ważności jako księga protokółów z posiedzeń zakonnych.

Umieszczono w niej także odpisy najważniejszych postanowień kongregacji jezuitów w Hiszpanii i Włoszech, a odnoszących się do zarządzania wiceprowincją, która istniała do 1575 r., a następnie prowincją jezuitów w Polsce. Odnajdujemy w niej także odpisy norm prowadzenia kolegów i szczegółowe zarządzenia do ich zarządzania. Znajduje się także alfabetycznie ułożony zbiór podstawowych dla jezuitów zagadnień związanych z prowadzeniem życia zakonnego. Opisano np. prawa i obowiązki przełożonych wobec współbraci.

\section{Rodzaj informacji}

Wiele miejsca poświęcono także działalności pisarskiej ówczesnego rektora wspólnoty w Poznaniu Jakuba Wujka. Dowiadujeny się m.in., że w lipcu 1571 r. Wujek pracował nad Postyllą, zaś brat Budzinski, w chwilach, gdy nie przepisywał rękopisów przełożonego, tłumaczył pieśni dla przyszłego kolegium i kościoła Towarzystwa Jezusowego w Poznaniu ${ }^{11}$. Pracę nad przygotowaniem się do efektywnych clzialan dydaktycznych wzmacniało rozpoczęcie przez Wujka i Szymona Wysockiego thumaczenia katechizmu Jakuba Ledesmy.

W styczniu $1574 \mathrm{r}$. w kościele Towarzystwa obyła się prezentacja dzieła Jakuba Wujka Postylli. Autor głosil opracowane przez siebie kazanie. Dawał tym samy przykład innym duchownym i zachęcał do używania jego pracy w gloszeniu slowa Bożego ${ }^{12}$.

W Kronice odnotowano np., że biskup Konarski przekazal superiorowi 350 florenów oraz obiecał jeszcze 3000 florenów na zakup clomu clla konwiktorów 
od pana Jankowskiego w Poznaniu ${ }^{13}$. W Dzienniku zaś odnajdujemy informacje: Małgorzata Kozłowska przekazała 200 florenów na leczenie naszych współbraci $^{14}$. Informacje o wsparciu finansowym w całej Kronice jak i Dzienniku Wielewickiego są bardzo liczne, co może świadczyć o przywiązywaniu do tego rodzaju zapisów wielkiej wagi. W zakonie ekonomowie prowadzili precyzyjne rozliczenia darowizn i wydatków, omawiane źródła koncentrują się jednak tylko wybiorczym wymienianiu darczyńców, zapewne tych, którzy byli szczególnie bliscy autorom zapisków.

Kronika starannie odnotowywała wszystkich gości kolegium ${ }^{15}$. Byli nimi m. in. przybyły z Rzymu Iustus Rabb (późniejszy członek komisji tłumaczenia Biblii na język polski) i powracający po odprawieniu rekolekcji w Braniewie Stanisław Herbest ${ }^{16}$. Bardzo szczegółowe odnotowywanie pobytu współbraci $z$ innych wspólnot było ważne ze względów finansowych. Rozliczano bowiem koszt takiego gościa i wystawiano jego domowi rachunek kosztów pobytu.

W Kronice możemy także odnaleźć opis wydarzeń związanych ze środowiskiem różnowierców poznańskich, czego przykładem jest zapis śmierci Łukasza Górki, którego oceniano jako największego przeciwnika Towarzystwa na ziemi wielkopolskiej ${ }^{17}$.

Nie mniej ważne dla autora Kroniki były zclarzenia związane $z$ walką o pozyskanie nowych wyznawców. W końcu 1576 r. miały w Poznaniu miejsce małe utarczki studentów kolegium ze środowiskiem zyclowskim. Wyznawca mojżeszowy Aleksander (takie imię mu nadano na chrzcie) Seps chciał przyjąc wyznanie katolickie. Pod protekcją wojewody udał się do jezuitów i chciał dopełnić nauk w kolegium. Przyjęcie go na terenie wspólnoty zakonnej uznano za bardzo bezpieczne. Podczas nieobecności wojewody Zydzi z Poznania porwali go, co spowodowało, iż studenci kolegium postanowili odbić Zyda, a to cloprowadzilo do walki w clzielnicy żydowskiej. W wyniku tego zajścia jezuiccy przełożeni otrzymali upomnienie od samego króla za brak pokory u swoich uczniów i porywczość. Jednak droga Żyda do Kościoła katolickiego zakończyła się pozytywnie. Dnia 1 stycznia 1577 r. przyjąl wraz z synami chrzest w kościele św. Marii Magdaleny ${ }^{18}$.

\section{Próba oceny źródel}

Wielewicki staral się w swoim Dzienniku zaprezentować historię domu profesów w kontekście wydarzeń dziejowych. Mało ważne zdarzenia z życia wspólnoty jezuickiej przedstawił na tle historii Rzeczypospolitej. Jak już zauważył Poplatek, autor Dziennika pragnął napisać dzieło, które miało spełniać funkcję edukacyjną dla przyszłych przełożonych w Towarzystwie Jezusowym. Kronika zaś jest pełnym opisem kolejnych dni wspólnoty jezuickiej, pozbawiona odniesień do wielkich wyclarzeń ze świata i Polski. Możliwość porównania dwóch wersji Kroniki daje pełniejszy obraz życia codziennego zakonników w XVI w.

Próba oceny wartości źródłowej Dziennika i Kroniki nastręcza pewne problemy. Wiele wydarzeń, a szczególnie tych wstydliwych było usuwanych $z$ dokumentów Towarzystwa Jezusowego. Przekładem może być opis wydarzeń z Poznania, zawartych w Kronice, w trakcie rektorstwa Jakuba Wujka. Otóż pod 
koniec 1575 r. Wujek miał poważny problem do rozwiązania we własnej wspólnocie. Doszło do konfliktu pomiędzy nim a o. Atriedą, z pochodzenia Hiszpanem, który poprzez swoje zachowanie narażał, jak oceniał Wujek, na szwank dobre imię zakonu i kolegium w Poznaniu. Jak wynika z zachowanej korespondencji, Hiszpan był posądzany o niewłaściwe praktyki wobec uczniów kolegium. Rektor określił jej jako mało religijne. Był upominany przez współbrata Jana Konarskiego, ale nie chciał powstrzymać się od clalszych kontaktów z uczniami. Chłopcy, którzy padli ofiarą jezuity, jak można wnioskować $z$ dalszej korespondencji, zostali usunięci ${ }^{19}$. Jakub Wujek, po naradzie $z$ konsultorami w Poznańskim domu, postanowił wysłać o. Atriedę do prowincjała w celu podjęcia ostatecznych decyzji. Problem $z$ Hiszpanem długo był tajemnicą ze względu na prowadzenie przez niego spowiedzi. Zakaz sprawowania sakramentu pokuty miał przywołać do porządku zakonnika, jednak spowodował eskalacje napięć we wspólnocie. Wujek bardzo ubolewał nad stratą nauczyciela, którego pod względem merytorycznym oceniał bardzo wysoko. Ale stracił jednocześnie nadzieję na jego nawrócenie i powrót do wspólnoty w Poznaniu ${ }^{20}$. Ze względu na brak zaufania, postanowił wysłać list do przełożonego poprzez osoby świeckie udające się do Wilna, a nie, jak dotychczas, poprzez brata Atriedę. Pod względem organizacyjnym odesłanie Hiszpana było dużą stratą, gdyż Kolegium zostało pozbawione nauczyciela teologii. W historii domu zakonnego odnotowano tylko wyjazd ojca 30 września, bez podania przyczyny, jednak dzięlki korespondencji możemy lepiej zrozumieć powód wyjazdu Hiszpana do ojca prowincjała $^{21}$. Ojciec Atrieda w styczniu 1576 r. został odesłany z Rzeczypospolitej do Rzeszy i otrzymał dymisję z zalkonu w 1578 r. Rektor zacząl czynić zabiegi o nowego wykładowcę. Prosił również o brata zakonnego, któremu mógłby powierzyć obowiązlki furtiana ${ }^{22}$.

Taki opis wyclarzeń znajdujemy we fragmencie Kroniki, który został przekreślony w wersji roboczej, nie znalazł już w uporządkowanym i starannie napisanym tekście.

\section{Wykorzystanie źródel}

Kronika domu poznańskiego została wykorzystana przez jezuitę Rafała Skrzyneckiego w XVIII w., który napisał jako pierwszy historię jezuitów w polskiej prowincji. Dzieło nie doczekało się druku, pozostaje nadal w ręlkopisie w Bibliotece Ossolinskich rkps. 628, Provinciae Poloniae Societatis Iesu ortus et progressus.

W literaturze przedmiotu bardzo rzadko znajdujemy odniesienia do historii kolegium poznańskiego czy Dziennika. Tak wielkie opracowania jak np. Stanislawa Obirka Jezuici w Rzeczypospolitej Obojga Narodów w latach 1564-1668, Kraków 1996, nie znajdziemy odniesień do tego źródła. Praca Wielewickiego tak potrzebna w XVII w., gdy rozwijało się Towarzystwo, stała się mniej przydatna dla historyków w czasach późniejszych. To raczej brak źródeł do historii zakonu w końcu XIX w. spowodował, że zdecydowano się wydać Dziennik. Nie znajdziemy w nim bowiem żadnych nowych faktów które mogłyby coś wnieść do historii Polski. Pobieżne potraktowanie wydarzeń w jakich uczestniczył nie 
stawiają jego pracy w pierwszym rzędzie podstawowych źródeł do dziejów Towarzystwa Jezusowego.

Jezuiccy historycy w Polsce, a za nimi badacze świeccy korzystają przede wszystkim z tzw. poloników z Archiwum Rzymskiego Towarzystwa Jezusowego. Ze źródeł niepublikowanych wykorzystywane są przede wszystkim dla XVI w. tzw. Catalogus triennalis i Catalogus brevis, które zawierają spisy obowiązków powierzonych poszczególnym jezuitom. Znajdziemy w nich juz tylko wersje zdarzeń poprawione przez prowincjałów i współbraci zakonnych. Potwierdza to przykład Kroniki z Poznania, gdzie możeny prześledzić zmiany, jakie były dokonywane na kartach tego źródła. Niestety bardzo wiele źródeł do historii jezuitów w Polsce zaginęło po kasacie zakonu.

W przedmowie do drugiego tomu Dziennika piszący wprowadzenie Chotkowski podkreślił: „Zapiski te miały być czynione wpierw na karcie, przedlkła- dane następnie prowincjałowi przy wizytacyi domu i dopiero po uzyskaniu jego aprobaty wpisywane do ksiag "23. Miał na myśli rozporządzenie generała zakonu Klaudiusza Aquavivy z 1608 r., w którym zawarto zalecenia co do porządkowania dokumentacji jezuickiej.

Taka ocena wydlaje się szczególnie słuszna wobec przykładu jakim jest zachowana kronika z Poznania. Porównując ją z Historia Collegii 1570-1653 znajclującą się w Bibliotece Jagiellońskiej pod sygnaturą 5198 III możemy stwierclzić, iż jest bardzo duża różnica w prezentacji np̣. czasów rektorowania Jakuba Wujka 1571-1579.

Analizując Dziennik jak i Kroniki zakonne możemy stwierdzić, iż korespondencja jezuitów zachowana m.in. w Archiwum Rzymskim jest najbarclziej wiarygodnym źródłem do badania dziejów zakonu niż np. dokumenty słane do kurii generalnej, które podlegały wielokrotnej obróbce cenzurze wewnątrzzakonnej.

\section{Przypisy:}

${ }^{1}$ Odpowiednik superiora-przełożonego wspólnoty, często prepozyt domu u św. Barbary zastępował prowincjała.

${ }^{2}$ Encyklopedia wiedzy o jezuitach na ziemiach Polski i Litwy 1564-1995, L. Grzebień, (oprac.), Kraków 1996, s. 733.

${ }^{3}$ J. Wielewicki: Dziennik spraw domu zakonnego, t. 10, Kraków 1986, s. 252.

${ }^{4} \mathrm{M}$. Wielewicz: Historia Collegii Leopoliensis Jesu manu propria R.P. Matthiae Wielewicz pro tunc rectoris diligentissime collecta et descripta ad anum 1669 quo anno obdormivit in Domino, Biblioteka Narodowa Austrii Cod. 11988.

${ }^{5}$ J. Sygański, (wyd.), Korespondencya księdza Jakóba Wujka z Wagrowca z lat 16691596, podlug autografów, „Roczniki Towarzystwa Przyjaciół Nauk Poznarískiego”, l. 4446, Poznań 1917-1920.

${ }^{6}$ Boszewo stanowilo majątek zakonu jaki otrzymali od bp. A. Noskowskiego, odbyly się tu trzy kongregacje: 1576, 1578 i 1593. Towarzystwo wybudowalo willę wypoczyn- 
kową wraz z kaplica, często korzystano z tego majątku w okresach zarazy: w: L. Grzebień, Ellcyklopedia, s. 60.

${ }^{7}$ HPCSI, s. 22v-23.

${ }^{8}$ Ibidem, s. 24-24v.

${ }^{9}$ Ibidem, s. 26v.

${ }^{10}$ L. Grzebień, Encyklopedia, s. 619.

${ }^{11}$ HPCSI, s. 101.

${ }^{12}$ Ibidem, s. 110.

${ }^{13}$ Ibidem, s. 103.

${ }^{14} \mathrm{~J}$. Wielewicki, Dziennik..., t. 7, s. 114.

${ }^{15}$ HPCSI, s. 106.

${ }^{16}$ Ibidem, s. 102.

${ }^{17}$ Ibidem, s. 106v.

${ }^{18}$ Ibidem, s. 132-132v.

${ }^{19}$ Jakub Wujek do Everarda Mercuriano 4 IV 1576 Poznani, J. Sygański, Korespondencya, t. XLIV, s. 354.

${ }^{20}$ Jakub Wujek do Everarda Mercuriano 28 X 1575 Poznań, ibidem, s. 349-350; HPCSI, s. 115.

${ }^{21}$ Jakub Wujek do Francesco Sunyera 30 X 1575 Poznań, J. Sygański, Korespondencya. t. XLIV, s. 351.

${ }^{22}$ W. Chotkowski, Przedmowa. w: J. Wielewicki, Dziennik, t. 10, Kraków 1986, s. VI. 